\title{
THE CASE OF THE SPELUNCEAN EXPLORERS IN THE SOUTH AFRICAN CONSTITUTIONAL COURT
}

\author{
Marius van Staden \\ LLB LLM \\ Lecturer, Public Law \\ University of Johannesburg
}

\begin{abstract}
SUMMARY
The South African legal profession is dealing with a hermeneutic turn in the way in which meaning of legislative provisions is discovered. Meaning is no longer discovered solely through the reading of the text of a provision, but in dealing with the textual environment of which that provision forms part. The article explores some of the interpretative considerations that the Constitutional Court would have to have regard to if it were called upon to judge a case similar to that of Fuller's "The Case of the Speluncean Explorers" - a fictionalized judgment set in the year 4300 and decided by the Supreme Court of Newgarth, but written by Fuller in 1949. The article draws a comparison between the interpretative approach adopted by the Constitutional Court and that of the five justices in the fictional case. Additionally, the article considers the phenomenon of the "broadening of the spectre of interpreters" which is a consequence of the approach adopted by the Constitutional Court, and asks what role, if any, public opinion should play in the interpretation of statutes. The article finds that these considerations should play a role in the interpretation of statutes in addition to other interpretative factors such as the text, history, purpose, context and values inherent to the South African legal order. The article concludes that interpretive debate in South Africa has failed in any real way to move beyond debates already dominant when the fictionalized judgment was written in 1949. It also reiterates the warning to the South African judiciary in particular, and the South African legal order in general, that allegiance to literalist and positivist traditional canons of statutory interpretation poses the risk of impeding the contribution which can be made by the judiciary to the transformation of South African society.
\end{abstract}

\section{1}

\section{INTRODUCTION}

Fuller's "The Case of the Speluncean Explorers" is a fictionalized judgment set in the year 4300 and decided by the Supreme Court of Newgarth. ${ }^{1}$ The court was evenly divided on the fate of Roger Whitmore's cave-exploring companions who cannibalized him in an act of desperation to ensure their survival. $^{2}$ Fuller uses this fictionalized account to illustrate how different approaches to the interpretation of statutes can affect the outcome of cases and, according to Eskridge, the five fictional judgments "constitute a microcosm of [twentieth-century] debates over the proper way to interpret

\footnotetext{
Fuller "The Case of the Speluncean Explorers" 194962 Harvard LR616.

Fuller 194962 Harvard LR 645.
} 
statutes". ${ }^{3}$ In fact, many more interpretations (and therefore outcomes) based on other theories have been put forward. ${ }^{4}$ Undoubtedly even more opinions are possible. Fuller succeeds in highlighting the schism between natural law and positivism, different approaches to statutory interpretation, and varying views on the roles of judges. ${ }^{5}$ The case may therefore be utilized to practically demonstrate the interrelationship between jurisprudential theory and the way the interpreter interprets legislative provisions. Each of the five judgments in the case may be seen as a particular manifestation of a particular theory of law prevalent in the twentieth century.

The question arises as to how the South African Constitutional Court would interpret a similar provision to that in the Speluncean Explorers' case under similar circumstances. Although it is not possible, because of the nuances and complexities of the subject field, to answer what exactly the interpretation of the Constitutional Court would be, it is still possible to enquire what the interpretative approach or methodology would most likely be (although some logical inferences may follow as necessary consequence of particular approaches). The phenomenon of the "broadening of the spectre of interpreters", 6 which is a consequence of the approach adopted by the Constitutional Court, and which asks what role, if any, public opinion should play in the interpretation of statutes, will also be considered. The formalistic view has long been that it is only the judiciary who interprets statutory provisions. ${ }^{7}$ But as Du Plessis points out, the "openness of a constitution and of constitutional interpretation brings to light something that, in statutory interpretation, is usually neglected: the fact that Courts are not the only authorised (and de facto) interpreters of the Constitution or statutes". 8 The alternative view is that interpretation is a public process where Courts, legislative and executive functionaries and in fact all citizens (even if they are cannibals) are interpreters of these provisions. Even when courts interpret, these processes are usually initiated by non-judicial readers, albeit generally with the aid of legal experts. ${ }^{9}$ The question is if any regard should be given by the judiciary to the interpretation attributed by extrajudicial parties (such as cannibals) to a legislative provision.

South Africa of 2014 is not Newgarth of 4300 nor the United States of 1949. Although Fuller sets his account in the future, the opinions therein are very much a manifestation of the time it was written. Eskridge argues that Fuller's world presents itself "as a world where the only actors who matter

3 Eskridge "The Case of the Speluncean Explorers: Twentieth-Century Statutory Interpretation in a Nutshell" 199361 Washington LR 17311732.

4 See, eg, D’Amato "The Speluncean Explorers - Further Proceedings" 198032 Stanford LR 467; Cahn, Calmore. Coombs, Greene, Miller, Paul and Stein "The Case of the Speluncean Explorers: Contemporary Proceedings" 199361 George Washington LR 1754; Suber The Case of the Speluncean Explorers: Nine New Opinions (1998); and Kozinski, Sunstein, West, De Bunker, Easterbrook and Butler "The Case of the Speluncean Explorers: Revisited" 1999112 Harvard LR 1876.

5 Shapiro "A Cave Drawing for the Ages" 1999112 Harvard LR 18341839.

6 Du Plessis "Interpretation" in Woolman and Bishop (eds) Constitutional Law of South Africa (2008) 32-45.

Marbury v Madison 5 US (1 Cranch) 137 (1803) 177.

Du Plessis in Woolman and Bishop (eds) Constitutional Law of South Africa 32-45.

9 Du Plessis in Woolman and Bishop (eds) Constitutional Law of South Africa 32-46. 
are male, white, affluent, and heterosexual". ${ }^{10}$ Nevertheless it may be argued that the South African debate surrounding the interpretation of statutes has failed in any real way to move beyond debates that were already at its zenith in 1949, ignoring or neglecting much debate that has followed elsewhere. This in spite of a progressive constitution that challenges South African lawyers to reimagine the role of law in contributing to the transformation of South African Society and the creation of a new legal order. ${ }^{11}$

\section{FACTS OF THE NEWGARTH CASE}

The facts of the case appear from the judgment of Chief Justice Truepenny. ${ }^{12}$ The Supreme Court of Newgarth was called upon to determine if four defendants were guilty of contravening Newgarth's statute which provided that "[w]hoever shall willfully take the life of another shall be punished by death". The four defendants were, together with Roger Whitmore, members of the Speluncean Society, an organization of amateurs who explored caves. Whilst in the interior of a limestone cavern, a landslide occurred. Heavy boulders blocked the opening to the cave. Although the explorers were able to communicate with the outside world, the rescue effort was met with overwhelming difficulty. Workmen, engineers and other experts had to be transported to the remote cite at great expense and a huge temporary camp was established. The effort was further hampered by fresh landslides and ten rescue workers died in the rescue attempt. The sum of eight hundred thousand frelars was expended before the defendants were finally freed.

The explorers had carried with them only scant provisions, and there was no food within the cave. It was soon realized that they might meet their death by starvation before they could be reached. On the twentieth day the engineers informed them that at least ten days would be required even if no new landslides occurred. Physicians agreed that they could not survive for ten days longer unless they consumed the human flesh of their fellow explorers. Whitmore asked if it were advisable for them to do so. No physician, judge, government official, minister or priest was willing to answer the question. No further messages were received from within the cave. When the defendants were finally freed it was learned that on the twentythird day after their entrance into the cave, Whitmore had been killed and eaten by his companions after a dice was cast and fell against him. They were indicted for the murder of Roger Whitmore, notwithstanding their defence of necessity.

\footnotetext{
Eskridge 199361 Washington LR 1750-1751.

Constitution of the Republic of South Africa, 1996 (hereinafter "the Constitution").

Fuller 194962 Harvard LR 616-618.
} 


\section{OPINIONS OF THE SUPREME COURT OF NEWGARTH}

The Supreme Court of Newgarth was composed of 5 justices. Chief Justice Truepenny held that the language of the Newgarth statute permits for no exceptions. ${ }^{13}$ He considers the conviction of the defendants as not only fair and wise but also as the only available course under the law. Even so, the Chief Justice finds himself sympathizing with the defendants and pleads with the leader of Newgarth to grant clemency, which he believes the leader of Newgarth will in fact do. From an interpretative perspective, the Chief Justice therefore endorses the notion that statutory language, when clear and unambiguous, must be decisive. ${ }^{14}$

Justice Foster constructed two arguments as to why the defendants should not be found guilty of murder. ${ }^{15}$ It was argued that the explorers, trapped in a cave, were effectively removed from Newgarth's jurisdiction (if not geographically, then morally) and that they were in a "state of nature". Newgarth's laws could therefore not apply to them because "[w]hen a situation arises in which the coexistence of men becomes impossible, then a condition that underlies all of our precedents and statutes has ceased to exist". ${ }^{16}$ The alternative argument assumes that, in fact, the defendants were under Newgarth's jurisdiction. Although the defendants violated the literal wording of the statute, statutes must be interpreted "reasonably, in the light of its evident purpose". The principle purpose of the statute was said to be to deter crime and therefore the defendants did not contravene the statute.

Justice Tatting withdrew from the decision of the case. ${ }^{17}$ The justice finds himself unable to dissociate the emotional and intellectual sides of his reactions. Although he is struck by the absurdity of convicting the defendants he takes issue with the opinion of Justice Foster. He identifies various conceptual problems associated with the notion of a state of nature such as the moment when the defendants passed from the jurisdiction of Newgarth law to that of "the law of nature", and what the contents of such a code of nature is. He questions purpose as interpretive device: "Assuming that we must interpret a statute in the light of its purpose, what are we to do when it has many purposes or when its purposes are disputed?"

Justice Keen believes that a distinction should be made between his personal feelings on the matter and the decisions that he must make in his public capacity as a judge. ${ }^{19}$ No judge should allow his personal feelings to enter into a case. He states that if it were up to him he would have freed the men, but as a judge it is not his task to consider matters of clemency or morality. The sole question to be answered was if the defendants had

\footnotetext{
Fuller 194962 Harvard LR616ff.

Shapiro 1999112 Harvard LR 1837.

Fuller 194962 Harvard LR $620 \mathrm{ff}$

Ibid.

Fuller 194962 Harvard LR 626ff.

Ibid.

Fuller 194962 Harvard LR $631 \mathrm{ff}$.
} 
contravened the statute and, as the statute allows for no exception, the defendants had to be found guilty. Justice Keen bases his argument on the supremacy of the legislature in which it is not the function of decision-makers to legislate freely. He also takes the use of purpose by Justice Foster to task: "not one statute in a hundred has any such single purpose, and ... the objectives of nearly every statute are differently interpreted by the different classes of its sponsors."

For Justice Handy the problem before the Court "is a question of practical wisdom, to be exercised in a context, not of abstract theory, but of human realities". ${ }^{21}$ It was noted that about ninety per cent of the public thought that the defendants should be pardoned or let off with a kind of token punishment. The judge also noted that he has learned, through a friend of the leader of Newgarth's secretary, that the leader would not grant clemency. He felt that the only result of a common-sense approach should be to find the defendants not guilty as this would best satisfy the public. The final vote on the Court was two against two (with Justice Tatting's withdrawal) and the decision of the Chief Justice was thus affirmed. The Speluncean Explorers were sentenced to death. ${ }^{22}$

\section{THE CONSTITUTIONAL COURT'S APPROACH TO THE INTERPRETATION OF STATUTES}

Klare has observed that lawyers in South Africa display a "relatively strong faith in the precision, determinacy and self-revealingness of words and texts" and that "legal interpretation in South Africa tends to be more highly structured, technicist, literal and rule-bound". ${ }^{23}$ Klare's charge is that statutory interpretation in South Africa resembles the approach of the Chief Justice and Justice Keen in the Case of the Speluncean Explorers. South African statutory interpretation had for a long time been rooted in positivism and, prior to the adoption of a justiciable constitution in South Africa, statutory interpretation more often than not proceeded in terms of the famous dictum in Venter $v R^{24}$ In terms of this "golden rule" the aim of interpretation was "to ascertain the intention which the legislature meant to express from the language which it employed". ${ }^{25}$ It was assumed that the legislature encodes its intention within the language of the statutory provision and that, when clear and unambiguous, the words would disclose the true meaning of the provision. ${ }^{26}$ Intentionalist thinking did not play a significant role as this approach was more literalist than intentionalist, allowing resort to interpretive aids outside the language of the provision so as to ascertain the intention of the legislature only if and when the language

Ibid.

Fuller 194962 Harvard LR 637ff.

Fuller 194962 Harvard LR 645.

Klare "Legal Culture and Transformative Constitutionalism" 199814 South African Journal of Human Rights 146168.

1907 TS 910.

Venter $v$ R supra 914-915.

Du Plessis in Woolman and Bishop (eds) Constitutional Law of South Africa 32-57. 
was ambiguous or vague. ${ }^{27}$ The chief problem of this approach was that it assumes that language has a fixed and ordinary effect so that the correct use thereof will always reveal the true intention of the author. ${ }^{28}$ But, as Du Plessis points out, language is always open-ended and makes for a proliferation of meanings. ${ }^{29}$ It has become commonplace that there is no objectively neutral language capable to convey with the utmost of certainty objective meaning from the drafter to the reader. ${ }^{30}$ Instead, as Fish points out, meaning can only become understood against a background of interpretive presumptions: "A meaning that seems to leap off the page, propelled by its own self-sufficiency, is a meaning that flows from interpretive [sic] assumptions so deeply embedded that they have become invisible." ${ }^{31}$ Fish implies that language cannot be clear. What can be clear to an interpreter is an understanding of what the language of a text prescribes as that person interpreted it. This understanding is shaped by "personal intellectual and moral preconceptions" and the interpreter's familiarity with the context. ${ }^{32}$

The advent of constitutional democracy has, at least at a formal level, significantly dealt a blow to the orthodox approach to statutory interpretation as described above. The notion of the "intention of the legislature" has been toppled by constitutional supremacy in South Africa. In Matiso $v$ The Commanding Officer, Port Elizabeth Prison, it was stated that "[t]he interpretative notion of ascertaining 'the intention of the Legislature' does not apply in a system of judicial review based on the supremacy of the Constitution, for the simple reason that the Constitution is sovereign and not the Legislature". ${ }^{33}$ Additionally, the Constitution itself requires interpreters to look beyond the text of provisions, even when clear and unambiguous. Section 39(2) of the Constitution states that anyone "[w]hen interpreting any legislation must promote the spirit, purport and objects of the Bill of Rights". In Investigating Directorate: Serious Economic Offences v Hyundai Motor Distributors (Pty) Ltd. In re: Hyundai Motor Distributors (Pty) Ltd v Smit the Constitutional Court stated that "[a]ll statutes must be interpreted through the prism of the Bill of Rights". ${ }^{34}$ As such, "broad" purposive interpretation is slowly supplanting (or has already supplanted, some may claim) the old "golden rule" of statutory interpretation as described above, ${ }^{35}$ moving decidedly in a direction that would have been favoured by Justice Foster. But purposivism cannot be regarded as a panacea for all the evils associated with conceptions such as literalism and intentionalism. Justice 
Tatting is quite right to point out that statutory provisions might have different and conflicting purposes. ${ }^{36}$ Three additional problems with purposivism have been identified by Du Plessis, leading the author to declare that "glib purposivism cannot be allowed to dominate constitutional interpretation in the same manner and to the same extent that [the orthodox approach] has conventionally been dictating statutory interpretation". ${ }^{37}$ Firstly, "the processes involved in constitutional and statutory interpretation are too complex to be captured in one essential(-ist) or predominant catchword". ${ }^{38}$ Secondly, it would not be true to state that construing a provision purposively would equate to a generous or broad interpretation which favours the values of our Constitution, as purpose can also be restrictive. ${ }^{39}$ In fact it is possible for a statute to have an entirely unconstitutional purpose. It would, for example, be possible for Parliament to adopt a statute which purports to (and in fact does) ban the wearing of religious dress. It would be difficult to imagine a situation where an interpretation which furthers this purpose would also favour the values of our legal order. Thirdly, it is accepted that purpose itself can only be determined through statutory interpretation. ${ }^{40}$

The species of purposivism endorsed by the Constitutional Court is not the same as that advanced by Justice Foster. Botha declares that "[t]he fundamental principle of statutory interpretation is that the purpose of the legislation must be determined in the light of the spirit, purport and objects of the Bill of Rights in the Constitution" ${ }^{41}$ It is striking that this principle endorses the purposivist approach whilst qualifying it at the same time. This method of statutory interpretation is generally referred to as "teleological interpretation", ${ }^{42}$ a "value-activating strategy", ${ }^{43}$ or the "value-coherent theory" of statutory interpretation. ${ }^{44}$ It has become commonplace for this principle to guide the interpretation of legislation and it has been endorsed by the Constitutional Court. The approach was best described in African Christian Democratic Party v Electoral Commission: ${ }^{45}$ "[C]ourts ... must understand ... provisions in the light of their legislative purpose within the overall ... framework. That framework must be understood in the light of the important constitutional rights and values that are relevant." ${ }^{46}$ According to Le Roux this "[b]roader approach" favoured by the Court has four distinct steps: Firstly, the purpose of the provision must be established. Secondly, it should be asked if "that purpose would be obstructed by a literal interpretation of the provision". If that is the case, thirdly, "an alternative interpretation of the provision that 'understands' its central purpose" must be adopted. Fourthly, it must be ensured "that the purposive reading of the

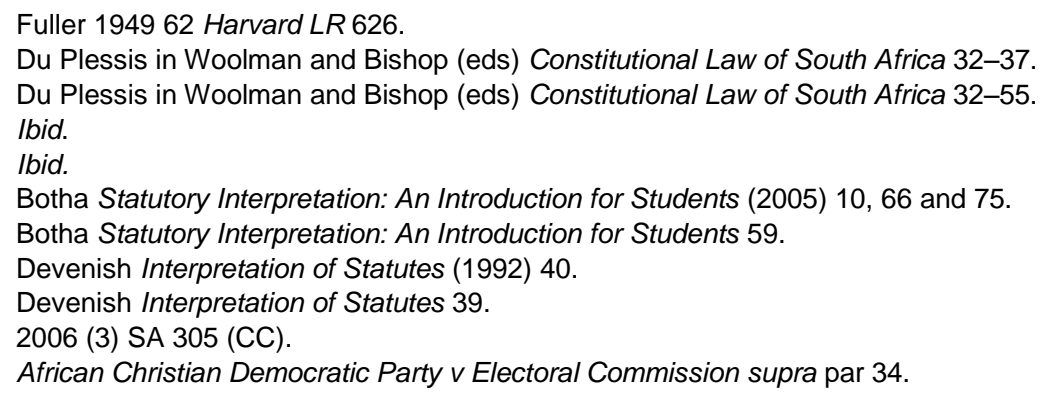


legislative provision also promotes the object, purport and spirit of the Bill of Rights". 47 It may thus be argued that "broad" purposivism with its alliance to constitutional values is a preferred alternative, and a solution, to the problems of conventional purposivism.

It would be incorrect to state that, because the Constitutional Court has endorsed a "broad" purposive approach, it has infiltrated South African legal culture. Klare's observation as to the propensity of South African lawyers to literalism is probably still, at least to a certain extent, just as accurate today. So, for example, the Supreme Court of Appeal has continued its reliance on orthodox and outdated modes of interpretation. ${ }^{48}$ Lip service to the new constitutionally mandated approach to the interpretation of statutes is not enough. Perhaps it can be argued that decision-makers (especially in the South African experience) are too loath in explaining which interpretative methodology they subscribe to. It is very rare for interpreters to explain exactly what theory, methodology, mode or approach they utilize in the interpretation of statutory provisions. Interpreters may not be consciously aware of their interpretive choices. Instead, the interpreter would often limit herself/himself to an averment that "the proper interpretation of A is B". Such averment undoubtedly rests on "the intellectual instincts and habits of mind of the traditional common or Roman-Dutch lawyer trained and professionally socialized during the apartheid era". ${ }^{49}$ Indeed "[l]egal culture has a powerful, steering or filtering effect on interpretive practices, therefore on adjudication, and therefore on substantive legal development" ${ }^{50}$ If South African decisionmakers would express their opinions more regularly and more openly ("the proper interpretation of A is B because the text is plain" or "the proper meaning of $A$ is $B$ because this would promote the purpose of the statute and further the constitutional value of equality"), it could allow healthy debate to take place as to the proper approach to the interpretation of statutes. Instead, it may be argued that, although the South African Constitutional Court has formally adopted a (qualified) Justice Foster-like approach, interpretation still regularly proceeds, because of legal culture, along Keensian lines. The result being that debate on the interpretation of statutes in South Africa remains "stuck" in mid-twentieth century thought.

\section{PUBLIC OPINION}

\section{Custom and the interpretation of statutes}

From a historic perspective, it is in fact very recently that it became accepted that the task of interpretation fell within the exclusive domain of the judiciary. In 1803 the United States Supreme Court in Marbury v Madison claimed for

\footnotetext{
47 Le Roux "Directory Provisions, Section 39(2) of the Constitution and the Ontology of Statutory Law: African Christian Democratic Party v Electoral Commission 2006 (3) SA 305 (CC)" 2006 South African Public Law 382386.

48 Refer in general to Du Plessis in Woolman and Bishop (eds) Constitutional Law of South Africa 32, fn 1, where the author lists a number of orthodox judgments; and contra Natal Joint Municipal Pension Fund v Endumeni Municipality 2012 (2) All SA 262 (SCA).

49 Klare 1998 South African Journal of Human Rights 156.

50 Klare 1998 South African Journal of Human Rights 148.
} 
the courts the peculiar "province and duty ... to say what the law is" including the exclusive power to impose definitive meaning on laws. ${ }^{51}$ Prior to this judgment and especially in the English context judges acted as legislatures and therefore statutory interpretation could not exist prior to the separation of these two branches of government as there was nothing "out there" to interpret. 52 Judge Hengham famously retorted to council in 1305: "Do not gloss the statute; we understand it better than you, for we made it."53

In the United States there has been some departure from the general rule of Marbury $v$ Madison within the case of agency interpretations of a statute; what Labuschagne would have called "toepassingsgewoontes": that is "gewoontes geïnisieer en toegepas deur staatsfunksionarisse en erken deur die regsprekende instansies". ${ }^{54}$ In Skidmore $v$ Swift it was said that courts should consider agency views for "persuasiveness" but courts themselves should determine the best available statutory meaning. ${ }^{55}$ In Chevron USA v Natural Res. Def. Council the Supreme Court mandated that an agency's interpretation of a statute be shown judicial deference when Congress had not spoken directly on the issue and the agency interpretation was reasonable. ${ }^{56}$ In United States $v$ Mead Corp the Supreme Court narrowed the range of agency statutory interpretations eligible for Chevron treatment and found that Chevron only applies where Congress has delegated lawmaking power to an agency and they properly invoke that power. ${ }^{57}$ Justice Scalia, writing in dissent, claimed that he knew of no case in the entire history of the federal courts, in which the Supreme Court has allowed a judicial interpretation of a statute to be set aside by an agency. ${ }^{58}$ Kelsen stated that: "[l]aw is always created by an act that deliberately aims at creating law, except where the law has its origin in custom, that is to say in a generally observed course of conduct, during which the acting individuals do not consciously aim at creating law". 59 Although these customs are seen to be "legislative" in nature (in the sense that they do not have to be applied by a court to acquire judicial force), they are also "judicial" in nature as the courts must still apply these rules in order to complete the legislative process. $^{60}$

Prior to 1994 our courts attached some interpretative weight to customs evolving on a vertical level - that is, those customs that have come into being as a result of the conduct of authorized functionaries of the State, if

\footnotetext{
Marbury v Madison 5 US (1 Cranch) 137 (1803) 177.

Popkin Statutes in Court: The History and Theory of Statutory Interpretation (1999) 9.

Avon YB 33 \& 35 Edw 1, 82 (Rolls Series).

Labuschagne "Op die Voetspoor van die Wetgewingsproses: Subsecuta Observatio en Contemporanea Expositio" 1979 De Jure 9196.

55 Skidmore $v$ Swift 323 US 134 (1944) 139-140.

56 Chevron USA v Natural Res. Def. Council 467 US 837 (1984) 842-845.

57 United States v Mead Corp 533 US 218 (2001) 226-227.

58 United States v Mead Corp supra 248.

59 Kelsen General Theory of Law and State (2009) 114.

60 Labuschagne 1979 De Jure 99.
} 
the statute was vague or ambiguous on a particular point. ${ }^{61}$ This was so as our Roman Dutch common-law and common-law writers expressed the sentiment that custom was the best interpreter of legislation. ${ }^{62}$ Interestingly, the writers also expressed the opinion that custom could even be used to strike down legislation although such notions were very soon done away with by the Appellate Division. ${ }^{63}$ Then again, parliamentary sovereignty and our common law have always been incompatible bedfellows.

The Constitution has reaffirmed that judicial authority, of which interpretation is an accepted parlance, is vested in the courts. ${ }^{64}$ The modus of statutory interpretation which has been endorsed by the Constitutional Court allows resort to factors outside the text of a legislative provision. ${ }^{65}$ The Constitutional Court has committed itself to a theory of interpretation which seeks to advance the values of our Constitution and our society. As such it would be unwise to disregard the values of our Roman-Dutch heritage. These values can augment and supplement constitutional values and must therefore be considered $a b$ initio.

\section{Public opinion and the interpretation of statutes}

In the case of the Speluncean Explorers it was of course not custom that was argued as a form of "judicial deference", but rather that the Newgarth Court had to take public opinion into consideration. ${ }^{66}$ For Rousseau, public

61 Refer to Vorster $v$ Muller and the Minister of Mines 1920 GWPA 126; Randfontein Estates Gold Mining Co Witwatersrand Ltd v Minister of Finance 1928 WPA 77; and Du Plessis v Gildenhuys 1965 (2) SA 478 (C).

62 Dig 13 37: optima enim est legume interpres consuentudo (custom is the best interpreter of statutes); Gomezius Variae Resolutiones 118 and 11 9: Item deficientibus his recurrendum est ad commune opinionem Doctorum (if the statute falls short, then the answer lies in the custom); Tuldenus Commentarius in Digesta 137 14: leges interpretationum, sumunt ex consuetudine, id est usu et observantia insecuta (an act can be interpreted through custom).

63 Zoesius Commentarius ad Digestorum 13 95: habet etiam consuetudo vim, legi tantum derogandi sed eam abrogandi, sive fit civilis sive etiam canonica (custom cannot merely amend legislation but legislation can also be abrogated thereby); Van Leeuwen Het RoomsHollands Regt 13 11: Maar indien op den sin ende op de uytlegging van enige Wetten, ofte Ordonnantien swaarigheid valt, is men gewoon hem naar het gewijsde daar over gehad, te gedragen. Green v Fitzgerald 1914 AD 88 111; and R v Detody 1926 AD 198201236.

64 S 165(1)-(3) of the Constitution states: "The judicial authority of the Republic is vested in the courts. The courts are independent and subject only to the Constitution and the law, which they must apply impartially and without fear, favour or prejudice. No person or organ of state may interfere with the functioning of the courts."

65 Refer to 4 above.

66 Note that at least one further instance of "judicial deference" may be possible in the form of a consideration by a court of the interpretation which affected parties would have attached or did attach to a statutory provision. Fuller ends all possible debate through his formulation of the facts that the explorers were uncertain as to what the law's dictates were and in that they tried to obtain a legal opinion from the outside world but failed to do so. The author therefore, through the formulation of the set of facts closes the debate as to whether the interpretive notions of the affected party should be taken into account at all. In President of the Republic of South Africa and Another v Hugo 1997 (4) SA 1 (CC) par 181 judge Mokgoro found that as a necessary incidence of the rule of law "[a] person should be able to know of the law, and be able to conform his or her conduct to the law". I have often wondered if, without diminishing the importance of the rule of law as a constitutional ideal, if 
opinion was of the utmost importance, even asserting that public opinion was a country's actual constitution. ${ }^{67}$ This view stood in stark contrast to the Socratic view that what is "right" is independent of the views held by the public. ${ }^{68}$ Most decision-makers do care about how they are viewed by the public, although how much they care and why they care are less certain. ${ }^{69}$ The question as to how, if at all, public opinion is to influence interpretation, is more vexed. There are ostensible benefits for a court in having regard to public opinion. ${ }^{70} \mathrm{An}$ interpretation which is in line with public opinion leads to better implementation thereof as it would reduce the chances that other branches of government will limit or reverse the decision of the court. ${ }^{71}$ Despite this it cannot be said that (unelected) judges would gain much in responding to public opinion. ${ }^{72}$ The incentives paid to these judges as individuals would incline them not to have regard to public opinion. ${ }^{73}$ Judicial decision-makers have made use of public opinion for a long time to determine the outcome of cases. ${ }^{74}$ In Planned Parenthood $v$ Casey Chief Justice Rehnquist and Justice Scalia, in their dissents, claimed that public opinion was constitutionally irrelevant, whilst Justice Souter partially relied on public opinion to uphold the constitutional right to an abortion, ${ }^{75}$ established in Roe $v$ Wade. ${ }^{76}$ Justice Souter argued that people would only accept judicial decisions "in which their principled character is sufficiently plausible to be accepted by the Nation". ${ }^{77}$ Justice Souter distinguished

other values such as equality, dignity and justice are not equally served by such a rule. In addition it should be pointed out that this rule has been acknowledged within our legal system in cases such as the famous $S v$ De Blom 1977 (3) SA 513 (A). In that case perhaps because of the vernacular of the criminal law, considerations of justice undoubtedly played an integral role to the determination of the case, although judge Rumpff does not quite phrase it in those terms. Instead, the judge based his decision that the maxim "every person is presumed to know the law" and "ignorance of the law is no excuse" has no place in the South African law on the argument that these maxims are out of place with the conception of culpability in criminal law (32). To my mind, a society committed to the rule of law must take seriously the knowledge that an affected person has about the legislative provision. S 1(c) of the Constitution states that the Republic of South Africa is founded upon the values of "supremacy of the Constitution and the rule of law".

67 Rousseau The Social Contract (1762; Sherover translation 1984) 272.

68 De Botton The Consolations of Philosophy (2000) 34.

Baum Judges and Their Audiences: A Perspective on Judicial Behaviour (2008) 71.

Baum Judges and Their Audiences: A Perspective on Judicial Behaviour 63.

Ibid.

72 Baum Judges and Their Audiences: A Perspective on Judicial Behaviour 64. The author at 61-63 refers to the benefits (both perceived and real) of elected judges in the United States of America in taking account of public opinion.

73 Ibid.

74 In the very early case of United States $v$ Hudson 11 US (7 Cranch) 32 (1812) 32, which involved the question if federal courts could recognize common-law crimes, the Supreme Court held that "[a]though this question is brought up now for the first time to be decided by this Court, we consider it as having been long since settled in public opinion. In no other case for many years has this jurisdiction been asserted; and the general acquiescence of legal men shows the prevalence of opinion in favor of the negative of the proposition". Planned Parenthood v Casey 112 S. Ct. 2791 (1992).

76410 US 113 (1973).

77 Planned Parenthood v Casey supra 2814. According to Wilson "The Role of Public Opinion in Constitutional Interpretation" 1993 Brigham Young University LR 10371044 "[o]ne reason 
between two conceptions of public opinion: those who evaluate an opinion against their own beliefs and those who believe in the rule of law. ${ }^{78}$ For him, the Court must be concerned with the latter and he therefore confirmed Roe $v$ Wade so as to create judicial consistency and to preserve the legitimacy of the Court. Put differently, it may be said that public opinion would favour a decision which serves the rule of law. Chief Justice Rehnquist found that it was the duty of the Court to "ignore the public criticism and protest that may arise as a result of a decision". ${ }^{79}$ Justice Scalia found that "[i]nstead of engaging in the hopeless task of predicting public perception - a job not for lawyers but for political campaign managers - the Justices should do what is legally right" ${ }^{80}$ He went on to question the impression that public opinion mattered: "How upsetting it is, that so many of our citizens ... think that we Justices should properly take into account their views, as though we were engaged not in ascertaining an objective law but in determining some kind of social consensus." ${ }^{81}$

In $S v$ Makwanyane the Constitutional Court was tasked with considering the constitutionality of capital punishment. ${ }^{82}$ One argument that was put forward was that public opinion in South Africa was firmly in favour of capital punishment. ${ }^{83}$ In disregarding public opinion Mahomed J, opined as follows:

"The difference between a political election made by a legislative organ and decisions reached by a judicial organ, like the Constitutional Court, is crucial. The legislative organ exercises a political discretion, taking into account the political preferences of the electorate which votes political decision-makers into office. Public opinion therefore legitimately plays a significant, sometimes even decisive, role in the resolution of a public issue such as the death penalty. The judicial process is entirely different."

If we were to accept a strict divide between law and politics then reliance upon public opinion during interpretation of legislative provisions would be largely regarded as inappropriate. It may therefore be argued that the disdain for public opinion was predicated upon an overly narrow view of the separation-of-powers doctrine and the role of the courts and an overly positivistic view of law where legal change is seen solely as a political process. ${ }^{85}$ In the Case of the Speluncean Explorers this is Justice Keen's argument. He rigidly separates statutory interpretation from politics:

"[A] question that I wish to put to one side is that of deciding whether what these men did was 'right' or 'wrong', 'wicked' or 'good'. That is ... a question that is irrelevant to the discharge of my office as a judge sworn to apply, not my conceptions of morality, but the law of the land.... From that principle [of

Justice Souter affirmed Roe was to create the judicial constancy that would sustain overall public respect for the Supreme Court, even if many members of the public disliked the Courts' protecting women's right to an abortion under the Constitution".

Wilson 1993 Brigham Young University LR 1044.

79 Planned Parenthood v Casey supra 2864.

Planned Parenthood $v$ Casey supra 2884.

81 Ibid.

82 S v Makwanyane 1995 (3) SA 391.

83 S v Makwanyane supra par 87.

$84 \quad S$ v Makwanyane supra par 265.

85 Morrison Jurisprudence: From the Greeks to Post-Modernism (1997) 423. 
legislative supremacy] flows the obligation of the judiciary to enforce faithfully the written law, and to interpret that law in accordance with its plain meaning without reference to our personal desires or our individual conceptions of justice."

For Justice Handy, however, law is a matter of practical politics and he has no problem in relying upon public opinion instead of the letter of the law (what Eskridge refers to as "realists' disdain", although the author believes that the Justice Handy's opinion is more a "caricature of realism"):

"[G]overnment is a human affair, and that men are ruled, not by words on paper or by abstract theories, but by other men. They are ruled well when their rulers understand the feelings and conceptions of the masses. They are ruled badly when that understanding is lacking. Of all branches of the government, the judiciary is the most likely to lose its contact with the common man."

Klare has pointed out that "[t]he common framing of the issues in traditional legal theory has the great weakness of insisting too sharply on a separation between law and politics and between professionally constrained legal practices and strategic pursuit of political and moral projects". ${ }^{99}$ This distinction is unsustainable because of the problems inherent in language. The openness of language has always produced a proliferation of meanings and decision-makers, when interpreting, will therefore be consciously or otherwise guided by factors present outside of the text. ${ }^{90}$

In $S v$ Makwanyane Chaskalson JP, remarked as follows on the use of public opinion as determining factor in adjudication:

"Public opinion may have some relevance to the enquiry, but in itself, it is no substitute for the duty vested in the Courts to interpret the Constitution and to uphold its provisions without fear or favour. If public opinion were to be decisive there would be no need for constitutional adjudication. The protection of rights could then be left to Parliament, which has a mandate from the public, and is answerable to the public for the way its mandate is exercised, but this would be a return to parliamentary sovereignty, and a retreat from the new legal order established by the Constitution. By the same token the issue of the constitutionality of capital punishment cannot be referred to a referendum, in which a majority view would prevail over the wishes of any minority. The very reason for establishing the new legal order, and for vesting the power of judicial review of all legislation in the courts, was to protect the rights of minorities and others who cannot protect their rights adequately through the democratic process. ... This Court cannot allow itself to be diverted from its duty to act as an independent arbiter of the Constitution by making choices on the basis that they will find favour with the public."

The statement above should, however, not be taken as an absolute disallowance of the use of public opinion. Chaskalson himself avers that

\footnotetext{
Fuller 194962 Harvard LR 632-633.

Eskridge 1993 Washington LR 1736

Fuller 194962 Harvard LR 638.

Klare 1998 South African Journal of Human Rights 159.

Klare 1998 South African Journal of Human Rights 157.

$91 S$ v Makwanyane supra par 88-89. Note that a similar opinion was advanced by Didcott $\mathrm{J}$, par 187, Kriegler J, par 206 and Madala J, par 259.
} 
public opinion may have some relevance to the inquiry and Kentridge AJ, states that "were public opinion on the question clear it could not be entirely ignored. The accepted mores of one's own society must have some relevance to the assessment whether a punishment is impermissibly cruel and inhuman." "What Kentridge advises here is for the judiciary not to lose touch with the "common man" as Justice Handy warns. In essence this is a charge of elitism. ${ }^{93}$ What is striking is that Justice Handy's criticism is aimed at both Justice Keen's literalism and Justice Foster's natural law (and purposive) approach. Both these approaches, argues Justice Handy, are pursuant to legal abstractions and theories which are removed from human realities. ${ }^{94}$ It is telling that Eskridge in apparent defence of Justice Keen (and in partial agreement with Handy) regards purposivism as the ultimate elitism: "Foster's theory of interpreting statutes to carry out their purposes is judicial lawmaking". ${ }^{95}$ He goes on to state that judicial lawmaking is questionable on grounds of elitism. ${ }^{96}$ Put differently, Eskridge views the source of elitism not as emerging from abstract and complicated legal theory (as Justice Handy holds) but from judicial law-making. Indeed, according to Eskridge, Justice Handy himself is elitist because of his unwillingness to apply the letter of the law (in what Eskridge views as unacceptable judicial law-making). This is so, claims the author, because Handy is unelected and therefore unaccountable "and more arrogant in asserting the rightness of his own views". ${ }^{97}$ If one were to accept the view, however, as put forward by Justice Handy and a (real life) contemporary scholar such as Klare, that there is no real difference between law and politics, then it becomes apparent that elitism is part and parcel of the adjudicative and interpretive process. But this would also be true even if a literalist approach is adopted. Eskridge shows why judicial lawmaking is elitist but fails to deal with the objection that law and its abstractions are elitist instruments, capable of forcing schisms between the public and the judiciary (and perhaps Government as a whole).

Let us accept for a moment that adjudication and interpretation in law (irrespective of our approaches thereto) are elitist. It is trite that judges would not be able to forgo their constitutionally assigned task of interpreting legislation and resolving disputes in favour of and in deference to public opinion. But it would be irresponsible for the judiciary to lose touch with common people. As Currie and De Waal point out: "[r]eferences to the principle of democracy in the Constitution are ... often followed by references to the ideas of openness, responsiveness and accountability". ${ }^{98}$ For the authors these ideas mean that government institutions, including the courts, must be responsive to the people which they govern. ${ }^{99}$

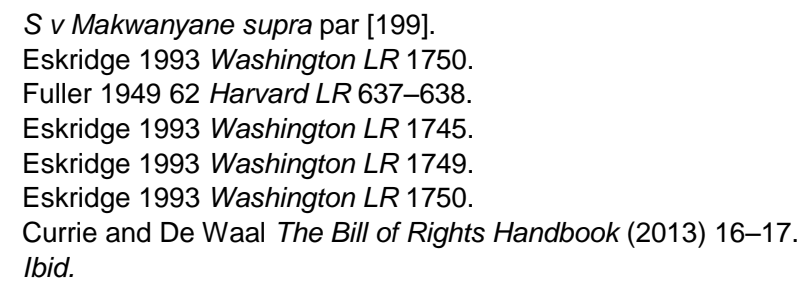


The middle-of-the-road solution of the Constitutional Court as per Chaskalson and Kentridge in Makwanyane seems to be the most workable. Public opinion and the interpretative task should not be seen as opposites but as mutually supportive. Recall that the Constitutional Court has endorsed an approach to the interpretation of statutes that goes beyond the mere achievement of statutory purpose but also seeks to further constitutional values. Democracy is a fundamental and central value in the Constitution. ${ }^{100}$ A proper interpretation of a statutory provision must therefore have regard to public opinion as a legitimate factor to be considered in the interpretive process, "comparable to text, history, structure, precedent and policy". ${ }^{10}$ This does not mean that decision-makers are at liberty to forgo proper constitutional inquiry in favour of total deference to public opinion. The weight which decision-makers must attached to public opinion would (and should) not be the same in all cases and it can be argued that the Constitutional Court in Makwanyane was correct in resisting public opinion in that case due to the importance of the constitutional right under consideration. ${ }^{102}$ Similarly, Wilson has argued that the "core" rights such as that all children should be able to attend public schools which were protected by the decision of the United States Supreme Court in Brown $v$ Board of Education means that the use of public opinion should be resisted in such cases. ${ }^{103}$

\section{CONCLUSION}

Two decades of democracy in South Africa has, with some exceptions, failed to produce vibrant debate as to the proper interpretation of statutes. Whilst professing allegiance to Fosteresque, broad purposivism (as mandated by the Constitution), it remains stuck in Keensian literalism (because of "an exaggerated concern to give the appearance of conforming to traditional canons of interpretive fidelity"). ${ }^{104}$ Modern debates on jurisprudential thought, such as critical race theory, feminist theory and post-structuralism (although intellectually stimulating) would have little practical significance if legal culture does not move beyond literalism and positivism. Klare poses a warning to judges in particular and the South African legal fraternity as a whole. ${ }^{105}$ Future generations will not judge the Constitutional Court on its allegiance to traditional interpretive notions but rather on the extent to which it contributed to the transformation of the South African society and legal order. ${ }^{106}$ The fact is that "the judiciary has through its power of interpretation

100 Ss $1,7,36,39,57,59,61,70,72,116,118,152,160,195,234,236$ and Chapter 9 of the Constitution.

101 Wilson 1993 Brigham Young University LR 1037 1040: "Indeed, some constitutional disputes, such as impeachment standards and proceedings, can only be effectively regulated by public opinion."

$102 \mathrm{~S} 11$ of the Constitution (the right to life).

103 Wilson 1993 Brigham Young University LR 1040-1041; Brown v Board of Education 347 US 483 (1954).

104 Klare 1998 South African Journal of Human Rights 171.

105 Klare 1998 South African Journal of Human Rights 172.

106 Ibid. 
the potential to contribute to the transformation of South African society". ${ }^{107}$ Instead, the judiciary and legal order would do well to rethink the role of judges and our conception of the separation of powers. It should be acknowledged that the judiciary is, together with the other branches of Government, equally responsible for the transformation of society. South Africa's grand transformative project should not be held to ransom because of overly positive, literalist and orthodox conceptions of the interpretation of statutes, steeped in outdated conceptions of the separation of powers. Instead, the courts should "press legal materials toward the limits of their pliability". ${ }^{108}$

107 Smit "Towards Social Justice: An Elusive and Challenging Endeavour" 20101 TSAR 111.

108 Klare 1998 South African Journal of Human Rights 171. 